\title{
Seasonal dynamics and phylogenetic diversity of free-living and particle-associated bacterial communities in four lakes in northeastern Germany
}

\author{
Martin Allgaier, Hans-Peter Grossart* \\ Leibniz-Institute of Freshwater Ecology and Inland Fisheries, Department of Limnology of Stratified Lakes, \\ Alte Fischerhütte 2, 16775 Stechlin-Neuglobsow, Germany
}

\begin{abstract}
The phylogenetic diversity and seasonal dynamics of free-living and particle-associated bacterial communities were investigated in the epilimnion of 4 lakes of the Mecklenburg Lake District, northeastern Germany. All lakes differed in their limnological features, ranging from oligotrophic to eutrophic and dystrophic. Bacterial community structure and seasonal dynamics were analyzed by denaturing gradient gel electrophoresis (DGGE) and clone libraries of 16S rRNA gene fragments. Communities of free-living and particle-associated bacteria greatly differed among the lakes. In addition, significant differences occurred between both bacterial fractions within each lake. Seasonal changes were more pronounced in free-living than in particle-associated bacterial communities. Non-metric multidimensional scaling (NMDS) analyses revealed several strong correlations between bacterial communities (both free-living and particle-associated) and environmental variables such as $\mathrm{pH}$, dissolved organic carbon (DOC), phytoplankton biomasses, and primary production. Phylogenetically, all cloned and sequenced 16S rRNA gene fragments belonged to already known freshwater clusters. Clone libraries of free-living bacteria were dominated by sequences of Actinobacteria, Bacteroidetes, and Betaproteobacteria, whereas those of particle-associated bacteria predominantly consisted of Cyanobacteria and Bacteroidetes sequences. Other freshwater phyla such as Alpha- and Gammaproteobacteria, Verrucomicrobia, Planctomycetes, and members of Candidate Division OP10 were found in low proportions. These differences may indicate an adaptation of distinct bacterioplankton communities to the respective environmental conditions of each lake.
\end{abstract}

KEY WORDS: Bacterioplankton communities · Phylogenetic diversity · Seasonal dynamics · Freshwater bacteria · DGGE · Clone libraries

\section{INTRODUCTION}

Heterotrophic bacteria are known to play a key role in biogeochemical processes and are responsible for the break-down of organic matter and the remineralisation of nutrients (Cotner \& Biddanda 2002). Until the late 1980 s, aquatic bacteria were considered as an entity or 'black box' without any further differentiation of their taxonomic composition. An important first step towards understanding the role of aquatic bacterial communities is the determination of the phylogenetic diversity of respective bacterioplankton communities (Cottrell \& Kirchman 2000a). The introduction of mole- cular methods to aquatic microbial ecology has facilitated the study of bacterioplankton community structure (Morris et al. 2002). Several studies have recently characterized bacterial community composition and dynamics of different aquatic habitats by cultureindependent methods such as denaturing gradient gel electrophoresis (DGGE) or sequence analyses of $16 \mathrm{~S}$ rRNA gene fragments (e.g. Rappé et al. 2000, Trusova \& Gladyshev 2002, Van der Gucht et al. 2005). However, there are fewer studies on freshwater than on marine bacterial communities. Although bacterial communities in freshwater are generally dominated by Betaproteobacteria, Actinobacteria, and members of 
Bacteroidetes, pronounced differences and variations are found between free-living and particle-associated bacterial communities (Weiss et al. 1996, Riemann \& Winding 2001, Schweitzer et al. 2001, Selje \& Simon 2003). Regardless, no comprehensive seasonal study of free-living and particle-associated bacterioplankton communities of different freshwater habitats exists yet.

Although many studies focus on the composition of freshwater bacterioplankton communities, surprisingly few examine the temporal and seasonal dynamics of bacterial communities in detail (Pinhassi \& Hagström 2000, Zwisler et al. 2003, Kent et al. 2004). Thus, seasonal and spatial dynamics of complex freshwater bacterioplankton communities are still poorly understood. Nevertheless, it has been shown that changes in environmental conditions significantly influence bacterial community structure throughout distinct seasons and periods (e.g. Langenheder \& Jürgens 2001, Crump et al. 2003, Kent et al. 2004). Various environmental variables, such as dissolved organic carbon (DOC), grazing by heterotrophic nanoflagellates, or phytoplankton biomass have been found to affect freshwater bacterial communities (Methé \& Zehr 1999, Pernthaler et al. 2001, Muylaert et al. 2002).

In this study we compared the seasonal dynamics and phylogenetic diversity of free-living and particleassociated bacterial communities of 4 selected lakes of the Mecklenburg Lake District, northeastern Germany, to assess (1) whether both bacterial fractions consistently differ from each other, (2) whether there are pronounced seasonal and spatial patterns in community structure of both fractions, and (3) whether observed patterns could be linked to environmental variables.

\section{MATERIALS AND METHODS}

Study sites and sample collection. Four lakes of different limnological features were selected for this study. All lakes were located in the same geographical region, the Mecklenburg Lake District (northeastern Germany), which was formed after the last ice age (Weichselian Stage). Oligotrophic Lake Stechlin and mesotrophic Lake Breiter Luzin are among the deepest lakes in this area (68.5 and $58.5 \mathrm{~m}$, respectively) and are both characterized by high hypolimnetic oxygen concentrations (up to $60 \% \mathrm{O}_{2}$ saturation). Lake Stechlin is situated in the middle of a mixed forest composed mainly of beech and pine trees, whereas the catchment area of Lake Breiter Luzin consists of natural forests and farm land.

In comparison, eutrophic Lake Tiefwaren is strongly influenced by anthropogenic activities. Extensive agriculture and industry in the late 1980s resulted in a hypertrophic state, but a restoration approach by a combination of aluminate and calcium hydroxide precipitation between 2001 and 2005 (Koschel et al. 2006) yielded its present eutrophic state.

The relatively small Lake Grosse Fuchskuhle is situated in a mixed forest and was artificially divided into 4 compartments (SW, NW, NE, SE) by large plastic curtains for biomanipulation experiments in the 1990s (Kasprzak 1993, Koschel 1995). Owing to large differences in their limnology (Bittl \& Babenzien 1996, Hehmann et al. 2001), the NE and SW compartments were selected for this study. The dystrophic SW compartment is the most acidic compartment of the lake ( $\mathrm{pH} 4.7$ ), because it is strongly influenced by the high input of humic matter from the adjacent bog area. The mesotrophic NE compartment receives less humic acids and is hence more neutral ( $\mathrm{pH}$ 6.5). A summary of the most important physicochemical and biological variables of all studied lakes is shown in Table 1.

All lakes were sampled monthly between April 2003 and March 2004, except during ice coverage in December (Lake Breiter Luzin), January (all lakes), and February (Lake Grosse Fuchskuhle). Composite water samples representing the epilimnion were collected with a Ruttner sampler at the deepest point of each lake. Based on thermal stratification, sub-samples were taken from 0, 5, and $10 \mathrm{~m}$ depth (April to May and October to March) or 0 and $5 \mathrm{~m}$ depth (June to September) in Lake Stechlin, Lake Breiter Luzin, and Lake Tiefwaren, respectively, and mixed in sterile glass flasks in equal volumes. Epilimnetic samples of the 2 compartments of Lake Grosse Fuchskuhle were collected as mixed samples from 0 and $2 \mathrm{~m}$ depth (April and October to March) or as surface samples (May to September), owing to the relatively shallow epilimnion. All water samples were transported to the laboratory in dark cooling boxes and processed 2 to $4 \mathrm{~h}$ after sampling.

DNA extraction and PCR amplification of 16S rRNA gene fragments. Particle-associated bacteria were retained by filtering 150 to $300 \mathrm{ml}$ of sample from each assay onto a $5.0 \mu \mathrm{m}$ Nuclepore membrane. Free-living bacteria were collected by filtering 100 to $150 \mathrm{ml}$ of the $5.0 \mu \mathrm{m}$ filtrate onto a $0.2 \mu \mathrm{m}$ Nuclepore membrane. Extraction of genomic DNA was performed using a standard protocol with phenol/chloroform/isoamylalcohol, SDS, polyvinylpyrrolidone, and zirconium beads (Allgaier \& Grossart 2006).

For DGGE analysis, a $550 \mathrm{bp}$ fragment of the 16S rRNA gene was amplified using the primer pair 341f and 907r (5'-CCTACGGGAGGCAGCAG-3' and 5'-CCGTCAATTCMTTTGAGTTT-3', respectively; Muyzer et al. 1998). At the $5^{\prime}$-end of primer $341 \mathrm{f}$, an additional 40 bp GC-rich nucleotide sequence (GCclamp) was added to stabilize migration of the DNA 
Table 1. Limnological characteristics of sampled lakes. $\mathrm{pH}, \mathrm{PO}_{4}$-Phosphate $\left(\mathrm{PO}_{4}-\mathrm{P}\right)$, dissolved organic carbon (DOC), bacterial number, primary production, and bacterial production data are average values of epilimnetic samples from Apr-Nov 2003 and Mar 2004; trophic status was determined following guideline EUR 14563 EN of the Commission of the European Communities (Premazzi \& Chiaudani 1992)

\begin{tabular}{|c|c|c|c|c|c|}
\hline \multirow{2}{*}{ Parameter } & \multirow{2}{*}{$\begin{array}{l}\text { Lake Stechlin }{ }^{\mathrm{a}} \\
\text { (ST) }\end{array}$} & \multicolumn{2}{|c|}{ Lake Grosse Fuchskuhle } & \multirow{2}{*}{$\begin{array}{l}\text { Lake Breiter } \\
\text { Luzin }^{\mathrm{c}} \\
\text { (BL) }\end{array}$} & \multirow{2}{*}{$\begin{array}{c}\text { Lake Tiefwaren } \\
\text { (TW) }\end{array}$} \\
\hline & & $\begin{array}{l}\text { NE basin } \\
\text { (FNE) }\end{array}$ & $\begin{array}{c}\text { SW basin } \\
\text { (FSW) }\end{array}$ & & \\
\hline Geographic position & $\begin{array}{c}53^{\circ} 10^{\prime} \mathrm{N} \\
13^{\circ} 02^{\prime} \mathrm{E}\end{array}$ & \multicolumn{2}{|c|}{$\begin{array}{l}53^{\circ} 06^{\prime} \mathrm{N} \\
13^{\circ} 02^{\prime} \mathrm{E}\end{array}$} & $\begin{array}{c}53^{\circ} 20^{\prime} \mathrm{N} \\
13^{\circ} 28^{\prime} \mathrm{E}\end{array}$ & $\begin{array}{c}53^{\circ} 31^{\prime} \mathrm{N} \\
12^{\circ} 42^{\prime} \mathrm{E}\end{array}$ \\
\hline Max. depth (m) & 69.5 & \multicolumn{2}{|c|}{5.6} & 58.5 & 24 \\
\hline Surface area $\left(\mathrm{km}^{2}\right)$ & 4.3 & \multicolumn{2}{|c|}{0.02} & 3.57 & 1.4 \\
\hline Catchment area $\left(\mathrm{km}^{2}\right)$ & 26.0 & \multicolumn{2}{|c|}{0.005} & 14.0 & 17.5 \\
\hline Stratification (2003) & Jun-Oct & May-Sep & May-Sep & Jun-Oct & Jun-Sep \\
\hline Secchi depth (m) & $6.5-10.5$ & $1.0-2.2$ & $0.9-1.5$ & $1.6-3.8$ & $3.1-8.9$ \\
\hline Trophic status & oligotrophic & eutrophic & dystrophic & mesotrophic & eutrophic \\
\hline $\mathrm{pH}$ & $8.5 \pm 0.2$ & $6.5 \pm 0.6$ & $4.7 \pm 0.2$ & $8.5 \pm 0.2$ & $8.3 \pm 0.2$ \\
\hline $\mathrm{PO}_{4}-\mathrm{P}\left(\mu \mathrm{gl}^{-1}\right)$ & $2 \pm 0.9$ & $5 \pm 2$ & $7 \pm 2$ & $3 \pm 4$ & $2 \pm 1$ \\
\hline $\mathrm{DOC}\left(\mathrm{mg} \mathrm{l}^{-1}\right)$ & $4.3 \pm 1.1$ & $10.3 \pm 1.3$ & $24.8 \pm 5.1$ & $5.8 \pm 0.6$ & $10.6 \pm 5.3$ \\
\hline Bacterial number $\left(10^{6} \mathrm{ml}^{-1}\right)$ & $1.35 \pm 0.58$ & $2.74 \pm 1.0$ & $1.93 \pm 0.69$ & $1.93 \pm 0.49$ & $2.21 \pm 0.47$ \\
\hline Primary production $\left(\mu \mathrm{gC} \mathrm{l}^{-1} \mathrm{~d}^{-1}\right)$ & $31 \pm 11$ & $182 \pm 156$ & $512 \pm 863$ & $103 \pm 44$ & $114 \pm 99$ \\
\hline Bacterial production $\left(\mu \mathrm{C} \mathrm{C}^{-1} \mathrm{~d}^{-1}\right)$ & $22 \pm 15$ & $39 \pm 21$ & $63 \pm 101$ & $51 \pm 58$ & $35 \pm 37$ \\
\hline
\end{tabular}

fragment in DGGE (Muyzer et al. 1993). The PCR reaction mixture contained 2 to $5 \mu$ template DNA, each primer at a concentration of $200 \mathrm{nM}$, each deoxyribonucleoside triphosphate at a concentration of $250 \mu \mathrm{M}, 2 \mathrm{mM} \mathrm{MgCl}, 5 \mu \mathrm{l}$ of $10 \times$ PCR reaction buffer, and $0.5 \mathrm{U}$ of BioTaq Red DNA polymerase (Bioline) in a total volume of $50 \mu \mathrm{l}$. PCR amplification was performed with a Gradient Cycler PT-200 (MJ Research) using the following conditions: initial denaturation at $95^{\circ} \mathrm{C}$ (3 min) followed by 30 cycles of denaturation at $95^{\circ} \mathrm{C}(1 \mathrm{~min})$, annealing at $55^{\circ} \mathrm{C}(1 \mathrm{~min})$, and extension at $72^{\circ} \mathrm{C}(2 \mathrm{~min})$. A final extension at $72^{\circ} \mathrm{C}$ for $10 \mathrm{~min}$ completed the reaction.

For clone libraries, the almost complete 16S rRNA gene was amplified using the primer pair 8f (5'AGAGTTTGATCMTGGCTCAG-3') and 1492r (5'GGYTACCTTGTTACGACTT-3') specific to the domain Bacteria (Muyzer et al. 1995). PCR conditions were as previously described (Allgaier \& Grossart 2006).

DGGE analysis of PCR products. PCR products were analyzed using the Ingeny PhorU DGGE-System (Ingeny) according to the protocol of Brinkhoff \& Muyzer (1997). DGGE was performed in a $7 \%(\mathrm{v} / \mathrm{v})$ polyacrylamide gel with a denaturing gradient of 40 to $70 \%$ urea and formamide. To obtain identical gradients among different DGGE gels, an automatic pump

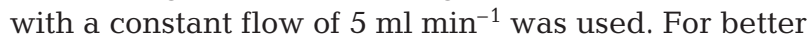
comparability of different DGGE profiles, PCR products were quantified on agarose gels using a quantitative DNA ladder (Low DNA Mass Ladder, Invitrogen), and similar amounts of DNA were loaded onto DGGE gels. All DGGEs were run in $1 \times$ TAE (tris acetate EDTA) electrophoresis buffer $(40 \mathrm{mM}$ Tris- $\mathrm{HCl}$ [pH 8.3], $20 \mathrm{mM}$ acetic acid, $1 \mathrm{mM}$ EDTA) for $20 \mathrm{~h}$ at a constant voltage of $100 \mathrm{~V}$ and constant temperature of $60^{\circ} \mathrm{C}$. Gels were stained with $1 \times$ SYBR Gold (Molecular Probes) and documented using an AlphaImager 2200 Transilluminator (Biozym). A mixture of DNA from 3 isolates derived from the studied lakes was used as an external standard to compare different DGGE gels.

Analyses of DGGE profiles and multivariate statistics. Bacterial communities of the 4 studied lakes were analyzed on different DGGE gels. Banding patterns were then compared among gels using the software GelCompar II version 3.5 (Applied Maths). The external standard was used to standardize the DGGE profiles of single gels and to perform correct and reliable band matching among different gels. We applied a 5 to $15 \%$ background subtraction depending on the signalto-noise ratio of the gels. Band-based binary presence/absence tables were calculated and single bands of each DGGE profile were scored using the minimum profiling tool of GelCompar II with a cut-off value of $5 \%$. Thus, all bands of at least $5 \%$ of the density of the darkest band were accounted as present. Position tolerances of $0.40 \%$ (free-living bacteria) and $0.48 \%$ (particle-associated bacteria) were applied to determine whether single bands from different gels were identical. Presence/absence tables were imported into the ordination software PC-ORD version 4.0 (MJM Software Design). We used non-metric multidimensional scaling (NMDS) ordinations instead of con- 
strained ordination techniques (e.g. canonical correspondence analysis [CCA]) to avoid distortions originating from the non-normal distribution of our species data obtained from DGGE profiles (McCune \& Grace 2002). NMDS uses only rank order information of a similarity matrix of samples rather than the original data matrix. In a first step, NMDS searches for the best model describing differences in bacterial community structure; in a second step, limnological variables are fitted independently to this model by means of multiple regression criteria. In contrast, constrained ordination techniques directly search for the most suitable model describing relationships between community data and environmental variables, accounting for both data sets at the same time.

Primary NMDS analyses of all gels were performed by a standard set-up using relativised Sørensen's distance measures, random starting coordinates, a stepdown from 6 to 1 dimensions, an instability criterion of $0.0001,300$ iterations to reach stability, 50 runs with real data sets, and 100 runs with the Monte Carlo permutation test (Mehner et al. 2005). The final run was performed with the optimum number of dimensions ( 2 to 5 dimensions) and the appropriate configurations as starting coordinates. Varimax rotation was applied to find corresponding groups and sample units. For the identification of particular environmental variables accounting for changes in bacterial community composition within the epilimnion of the lakes, Pearson's product moment correlations of limnological variables and DGGE profiles were calculated on the significant ordination axes.

Analysis of similarity (ANOSIM, Clarke \& Green 1988) was used to statistically test the significance of differences between the DGGE banding patterns of freeliving and particle-associated bacteria. ANOSIM generates a test statistic $(\mathrm{R})$ that is an indication of the degree of separation between groups. A score of 1 indicates complete separation, whereas a score of 0 indicates no separation. Equal to NMDS analyses, ANOSIM is based on a similarity matrix and not the original data matrix. ANOSIM analyses were conducted with software PRIMER 5 version 5.2.9 (PRIMER-E).

Construction of clone libraries. Cloning of the almost complete 16S rRNA gene fragments of freeliving and particle-associated bacteria was performed using the pGEM-T-Easy Vector System II (Promega) according to the manufacturer's protocol. Clone libraries were constructed for samples collected in May 2003 (Lake Stechlin only) and November 2003 (all lakes). A total of 19 to 29 clones from each clone library were selected and sequenced as described previously (Allgaier \& Grossart 2006).

Phylogenetic analyses. Partial sequences were assembled and corrected manually using the software
Chromas version 1.45 (Griffith University). Phylogenetic reconstructions were performed using the ARB software package (http://arb-home.de). 16S rRNA gene sequences of the clone libraries were first checked and classified by the basic local alignment search tool (BLAST; www.ncbi.nlm.nih.gov/BLAST/) and the RDP-classifier of the Ribosomal Database Project (http://rdp.cme.msu.edu/). Sequences were then imported into the ARB database of ca. 52000 reference sequences, including the closest related sequences determined by BLAST. Sequences were aligned automatically using the integrated alignment module within the ARB package and subsequently corrected manually. For the stability of phylogenetic trees, backbone trees that comprised sequences of only $\geq 1400$ nucleotides were calculated first. Validity of branching patterns of the trees was checked by applying 3 phylogenetic reconstruction methods - neighbor-joining, maximum parsimony, and maximum likelihood - to the appropriate sets of sequences. Sequences $\leq 1400$ nucleotides were added to the trees afterwards according to maximum parsimony criteria. This tool does not correct for evolutionary distances, and does not allow changes in overall tree topology.

Nucleotide sequence accession numbers. Obtained 16S rRNA gene sequences were deposited in GenBank with the following accession numbers: DQ501285 to DQ501378.

\section{RESULTS}

\section{Analyses of DGGE banding patterns}

DGGE banding patterns of free-living and particleassociated bacteria exhibited distinct differences with regard to bacterial community composition and seasonal dynamics (e.g. Fig. 1). Free-living and particleassociated bacterial communities differed significantly among the 4 lakes ( $\mathrm{p} \leq 0.01)$, as indicated by the formation of lake-specific clusters of DGGE profiles in NMDS analyses (Fig. 2A). Within free-living bacteria, DGGE profiles of Lake Breiter Luzin, Lake Stechlin, and the 2 compartments (NE and SW) of Lake Grosse Fuchskuhle exhibited clearly separated clusters, whereas DGGE banding patterns of Lake Tiefwaren overlapped with those of the NE compartment of Lake Grosse Fuchskuhle (Fig. 2A). Although the formation of lake-specific clusters within particle-associated bacteria was statistically significant ( $p \geq 0.01$ ), it was less obvious than for free-living bacterial communities (Fig. 2A).

Comparison of DGGE profiles from each single lake revealed significant differences between free-living and particle-associated bacterial communities (Fig. 2B, 

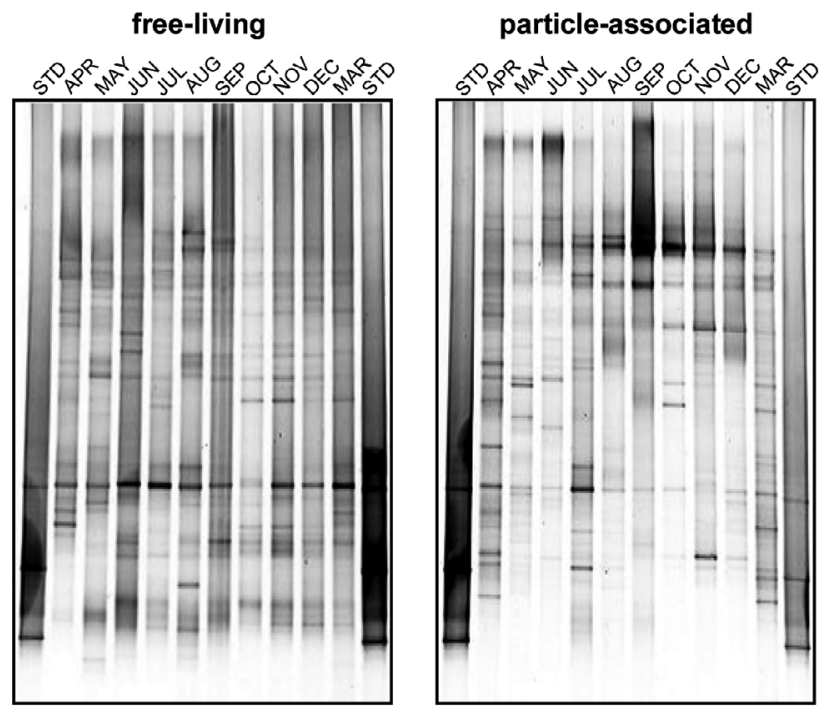

Fig. 1. DGGE profiles of amplified 16S rRNA gene fragments from free-living and particle-associated bacteria from the NE compartment of Lake Grosse Fuchskuhle, collected between April 2003 and March 2004. STD: standard

Table 2). Additionally, NMDS analyses indicated seasonal changes in bacterial community composition as depicted by the formation of season-specific clusters of samples within NMDS plots (Fig. 2B). Season-specific clusters varied among lakes and between bacterial fractions. In general, winter and spring samples of free-living bacteria clustered together and were clearly separated from samples taken in summer and fall. Formation of seasonal clusters within particleassociated bacteria was less pronounced compared with free-living bacterial communities.

\section{Sequence analyses of clone libraries}

To obtain more detailed information on the phylogenetic diversity of free-living and particle-associated bacteria of the studied lakes, clone libraries of $16 \mathrm{~S}$ rRNA gene fragments were constructed and sequenced. Altogether, 12 clone libraries from May (Lake Stechlin only) and November (all lakes) resulted in a total of 277 clones (Table 3). As determined by BLAST and the RDP classifier, 16S rRNA gene sequences of free-living bacteria belonged to Actinobacteria (44.4\% of total sequences), Bacteroidetes $(14.6 \%)$, Betaproteobacteria $(10.4 \%)$, Cyanobacteria $(10.4 \%)$, Alphaproteobacteria (8.3\%), Deltaproteobacteria $(1.4 \%)$, Candidate Division OP10 $(1.4 \%)$, Gammaproteobacteria $(0.7 \%)$, and chloroplasts $(3.5 \%)$. Contributions of other bacterial phyla such as Chlorobi, Thermomicrobia or Acidobacteria were very low

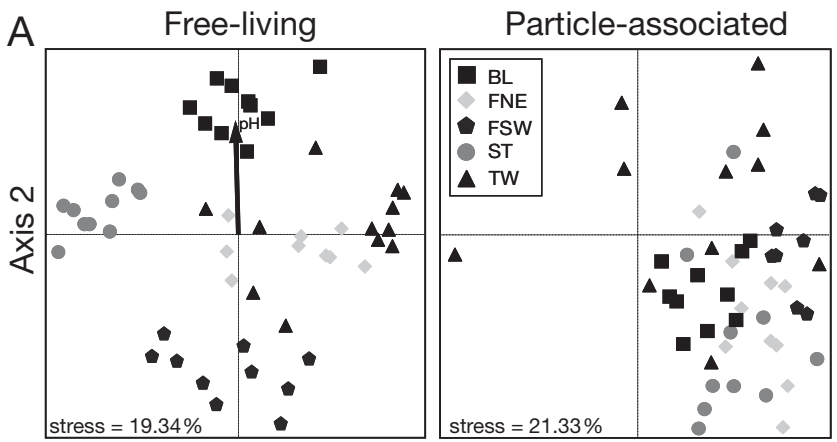

Axis 1

B
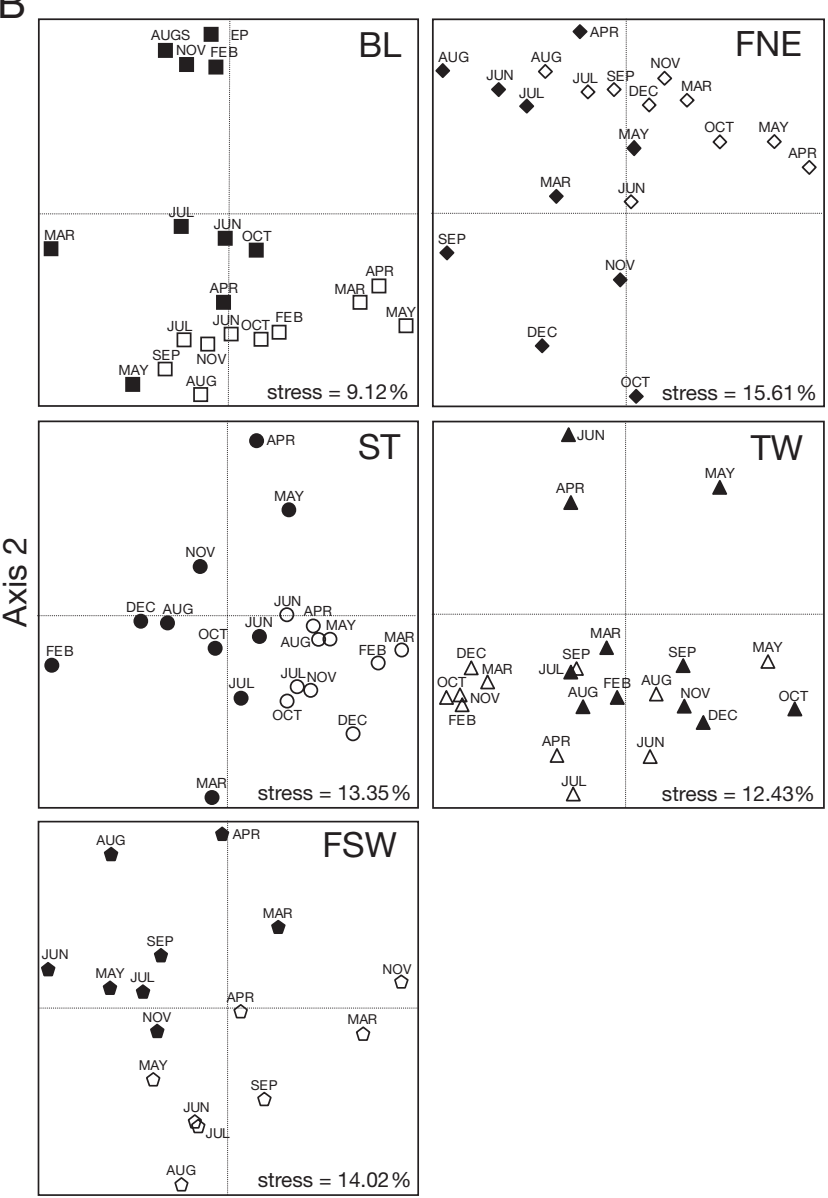

Axis 1

Fig. 2. Non-metric multidimensional scaling (NMDS) ordinations of DGGE banding patterns of free-living and particleassociated bacterial communities from the 4 studied lakes. Results from the first 2 ordination axes are given. (A) NMDS plots of all lakes; free-living bacteria were shown to be strongly correlated with $\mathrm{pH}$. (B) NMDS plots of single lakes. Open symbols: free-living bacteria; solid symbols: particleassociated bacteria. Abbreviations of lakes given in Table 1

(comprising a total of $4.9 \%$ ). Excluding sequences of chloroplasts from eucaryotic algae, 16S rRNA gene sequences from clone libraries of particle-associated bacteria were affiliated with Cyanobacteria $(43.5 \%)$, 
Table 2. ANOSIM statistics from comparison of DGGE profiles of free-living and particle-associated bacteria from each single lake. Global test revealed a sample statistic of 0.499 with a significance of $\mathrm{p} \leq 0.001$. FL: free-living; PA: particleassociated. Abbreviations of lakes given in Table 1; values significant at $\mathrm{p} \leq 0.05$ in bold

\begin{tabular}{|lcc|}
\hline & Sample statistic (R) & $\mathrm{p}$ \\
\hline BL (FL vs. PA) & 0.462 & $\mathbf{0 . 0 0 1}$ \\
FNE (FL vs. PA) & 0.245 & 0.08 \\
FSW (FL vs. PA) & 0.475 & $\mathbf{0 . 0 0 1}$ \\
ST (FL vs. PA) & 0.459 & $\mathbf{0 . 0 0 1}$ \\
TW (FL vs. PA) & 0.289 & $\mathbf{0 . 0 0 1}$ \\
\hline
\end{tabular}

Bacteroidetes (24.2\%), Alphaproteobacteria (8.1\%), Planctomycetes (4.8\%), Betaproteobacteria (3.2\%), Gammaproteobacteria (3.2\%), Verrucomicrobia (3.2\%), Candidate Division OP10 (1.6\%), and Actinobacteria $(1.6 \%)$.

In general, clone libraries of free-living bacteria were dominated by Actinobacteria, members of Bacteroidetes, and Betaproteobacteria. Actinobacteria sequences occurred in consistently high numbers in all 4 lakes. Members of Bacteroidetes were found mainly in Lake Stechlin (May and November), Lake Tiefwaren, and the SW compartment of Lake Grosse Fuchskuhle. No Bacteroidetes were found within free-living bacteria of Lake Breiter Luzin. Sequences of Betaproteobacteria occurred in relatively high numbers in Lake Stechlin (November only), Lake Breiter Luzin, and the NE compartment of Lake Grosse Fuchskuhle (Table 3). Cyanobacterial 16S rRNA gene sequences were present almost exclusively in the May 2003 clone library of free-living bacteria from Lake Stechlin.
When excluding sequences of chloroplasts from eucaryotic algae, clone libraries of particle-associated bacteria were dominated by sequences of Cyanobacteria and members of Bacteroidetes. Clones of Bacteroidetes were found in Lake Tiefwaren, Lake Stechlin (May), Lake Breiter Luzin, and the NE compartment of Lake Grosse Fuchskuhle (Table 3). Sequences of Cyanobacteria were almost only present in Lake Breiter Luzin, Lake Tiefwaren, and Lake Stechlin (May and November). Other phylogenetic lineages such as Verrucomicrobia or Planctomycetes occurred in low proportions.

Detailed phylogenetic reconstructions of free-living and particle-associated bacterial 16S rRNA gene sequences confirmed the phylogenetic classification retrieved by BLAST and RDP (Fig. 3). Because this study focused on heterotrophic bacteria, no phylogenetic trees were constructed for Cyanobacteria or chloroplast sequences. In general, free-living and particleassociated bacteria were equally distributed throughout the constructed phylogenetic trees and no distinct lake-specific or bacterial fraction-specific clusters appeared. A further separation into classes within Bacteroidetes is clearly visible in the phylogenetic tree in Fig. 3B. The majority of the $16 \mathrm{~S}$ rRNA gene sequences of Bacteroidetes belonged to Class Sphingobacteria. Only 8 sequences were affiliated to Class Flavobacteria and 3 sequences to Class Bacteroidetes, respectively.

Actinobacterial 16S rRNA gene sequences were phylogenetically affiliated with the freshwater clusters acI, acII, acIV, and acSTL, and with the clusters Soil I-III and Microthrix. Detailed descriptions of the diversity and phylogenetic relationship of actinobacterial sequences of this study are given by Allgaier \& Grossart (2006).

Table 3. Phylogenetic classification of 16S rRNA gene sequences derived from 12 clone libraries of free-living and particleassociated freshwater bacterial communities. FL: free-living bacteria; PA: particle-associated bacteria; n: number of sequences retrieved from each fraction. Abbreviations of lakes given in Table 1. ${ }^{\text {M}}$ Samples from May 2003, ${ }^{\mathrm{N}}$ samples from November 2003

\begin{tabular}{|c|c|c|c|c|c|c|c|}
\hline & $\begin{array}{c}\mathrm{ST}^{\mathrm{M}} \mathrm{FL} / \mathrm{PA} \\
\mathrm{n}=29 / 20\end{array}$ & $\begin{array}{c}\mathrm{ST}^{\mathrm{N}} \mathrm{FL} / \mathrm{PA} \\
\mathrm{n}=23 / 19\end{array}$ & $\begin{array}{c}\mathrm{BL}^{\mathrm{N}} \mathrm{FL} / \mathrm{PA} \\
\mathrm{n}=27 / 28\end{array}$ & $\begin{array}{c}\mathrm{FNE}^{\mathrm{N}} \mathrm{FL} / \mathrm{PA} \\
\mathrm{n}=20 / 20\end{array}$ & $\begin{array}{c}\mathrm{FSW}^{\mathrm{N}} \mathrm{FL} / \mathrm{PA} \\
\mathrm{n}=20 / 25\end{array}$ & $\begin{array}{c}\mathrm{TW}^{\mathrm{N}} \mathrm{FL} / \mathrm{PA} \\
\mathrm{n}=25 / 21\end{array}$ & $\begin{array}{c}\Sigma \mathrm{FL} / \mathrm{PA} \\
\mathrm{n}=144 / 133\end{array}$ \\
\hline Alphaproteobacteria & $2 /-$ & $-/ 3$ & $2 / 1$ & $-/ 1$ & $2 /-$ & $6 /-$ & $12 / 5$ \\
\hline Betaproteobacteria & $1 /-$ & $3 / 1$ & $4 /-$ & $5 / 1$ & $-1-$ & $2 /-$ & $15 / 2$ \\
\hline Gammaproteobacteria & $-/ 2$ & $-/-$ & $-/-$ & $-1-$ & $-1-$ & $1 /-$ & $1 / 2$ \\
\hline Deltaproteobacteria & $-1-$ & $1 /-$ & $-/-$ & $1 /-$ & $-/-$ & $-/-$ & $2 /-$ \\
\hline Actinobacteria & $7 / 1$ & $13 /-$ & $16 /-$ & $11 /-$ & $7 /-$ & $10 /-$ & $64 / 1$ \\
\hline Bacteroidetes & $3 / 3$ & $4 /-$ & $-/ 3$ & $2 / 2$ & $9 / 1$ & $3 / 6$ & $21 / 15$ \\
\hline Candidate Division OP10 & $0 \quad 1 /-$ & $-/ 1$ & $1 /-$ & $-/-$ & $-/-$ & $-/-$ & $2 / 1$ \\
\hline Planctomycetes & $-1-$ & $-/ 1$ & $-/ 2$ & $-1-$ & $-1-$ & $-1-$ & $-/ 3$ \\
\hline Verrucomicrobia & $-1-$ & $-/ 1$ & $-/-$ & $-1-$ & $-/-$ & $-/ 1$ & $-/ 2$ \\
\hline other phyla ${ }^{a}$ & $-1-$ & $1 /-$ & $2 / 2$ & $1 /-$ & $-/-$ & $3 / 2$ & $7 / 4$ \\
\hline Cyanobacteria & $12 / 2$ & $1 / 3$ & $2 / 17$ & $-1-$ & $-1-$ & -15 & $15 / 27$ \\
\hline Chloroplasts & $3 / 12$ & $-/ 9$ & $-/ 3$ & $-/ 16$ & $2 / 24$ & $-/ 7$ & $5 / 71$ \\
\hline
\end{tabular}




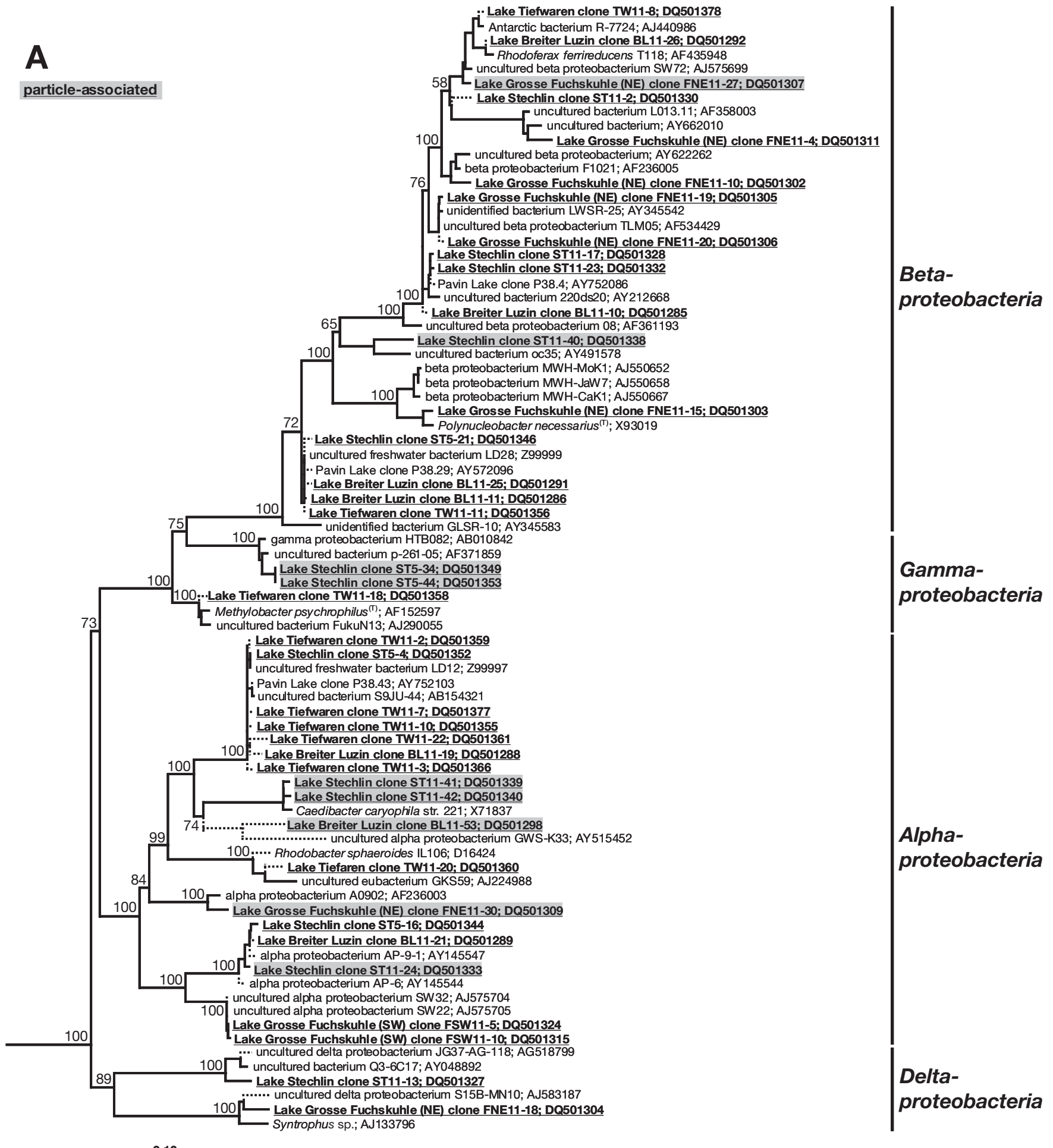

Fig. 3. (Above and following 2 pages). Maximum likelihood trees of cloned and sequenced 16S rRNA gene fragments from freeliving and particle-associated bacteria. Solid lines indicate sequences that were included in primary analyses (sequences $\geq 1400$ nucleotides), whereas dotted lines indicate partial sequences ( $\leq 1400$ nucleotides) added by maximum parsimony criteria. All sequences from this study shown in bold, underlined. Sequences of particle-associated bacteria are additionally shaded grey. GenBank accession numbers and bootstrap values at main branching points are given; scale bar corresponds to 10 base substitutions per 100 nucleotide positions. (A) Proteobacteria, (B) Bacteroidetes, (C) overall phylogenetic tree of 16S rRNA gene sequences that occur only in low numbers in clone libraries 


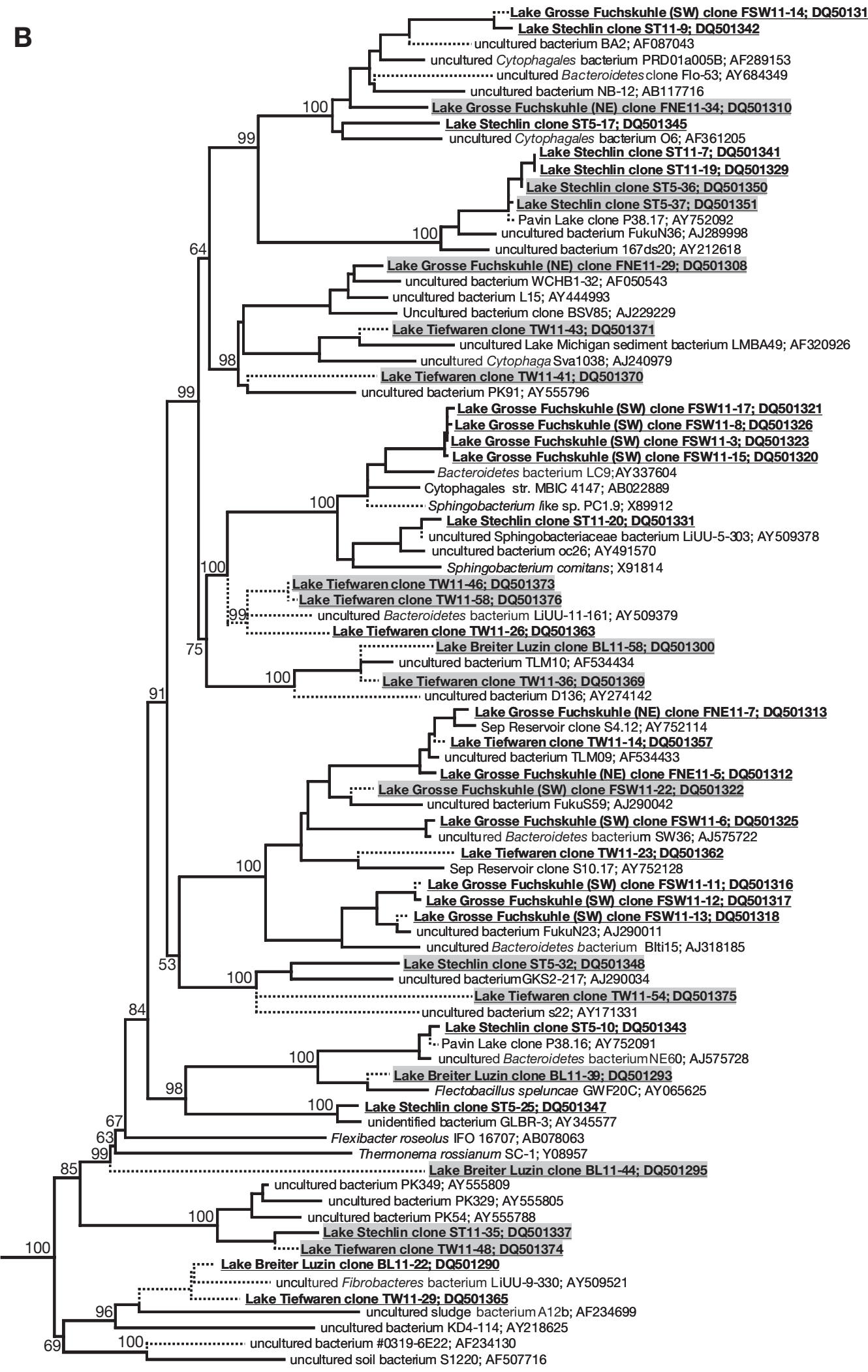




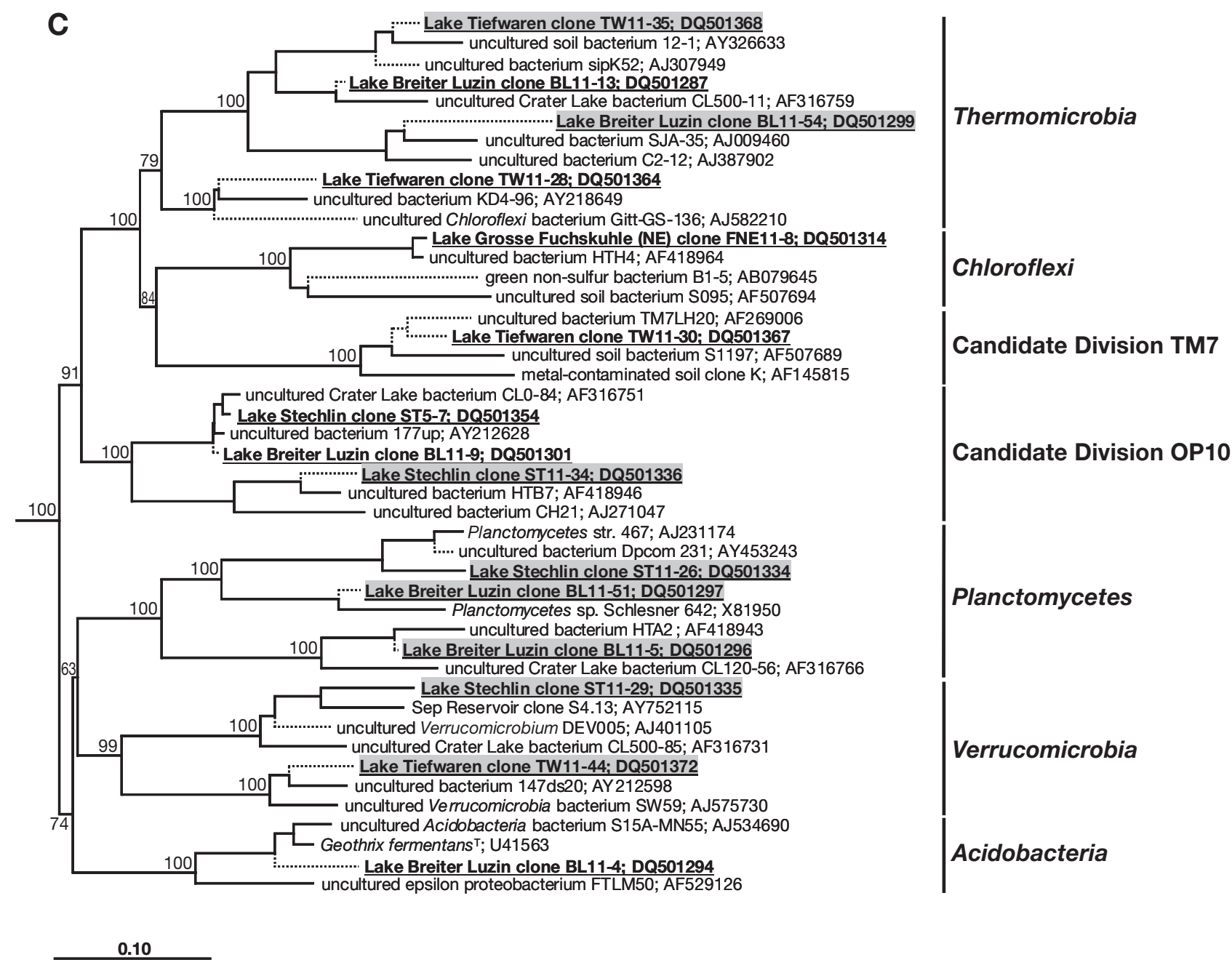

Fig. 3. (continued)

\section{Relationships between DGGE profiles and environmental variables}

Identification of potential relationships between limnological variables and seasonal changes within freeliving and particle-associated bacterial communities were performed by NMDS analyses because of the non-normal distribution of species data. Fifteen limnological variables were used for these analyses: secchi depth, temperature, conductivity, $\mathrm{pH}$, total nitrogen, total phosphorus, oxygen concentration, DOC, total bacterial number, bacterial protein production (total, free-living, and particle-associated), phytoplankton and zooplankton biomass, as well as total primary production.

NMDS analyses were separately performed for freeliving and particle-associated bacteria from each single lake, and with a combined data set composed of both bacterial fractions. In addition, 2 comprehensive data sets of free-living and particle-associated bacteria were analysed, comprising DGGE profiles and limnological variables of all studied lakes. Pearson's product moment correlations of the combined data sets of freeliving and particle-associated bacteria of the single lakes revealed only weak correlations (Pearson's $r \leq 0.7$, data not shown). In contrast, separate analyses of free-living and particle-associated bacterial communities exhibited several distinct correlations with environmental variables, such as temperature, $\mathrm{pH}, \mathrm{DOC}$, bacterial production, primary production, and phytoplankton biomass (Table 4). However, no consistent correlation patterns were observed between all lakes and both bacterial fractions. Comprehensive statistical analyses that included all epilimnetic samples revealed a strong correlation between free-living bacteria and $\mathrm{pH}(\mathrm{r}=0.785$, Table 4). As indicated in Fig. 2A, pH was highly correlated with the free-living bacteria of Lake Breiter Luzin. 
Table 4. Non-metric multidimensional scaling ordinations and Pearson's product moment correlations between DGGE profiles of free-living and particleassociated bacterial communities and limnological variables. Pearson's r-values $\geq 0.7$ are given for 3 significant ordination axes; limnological variables with $r \leq 0.7$ were excluded. First column gives results of comprehensive analyses of epilimnetic samples from all lakes. DOC: dissolved organic carbon; BPP: bacterial protein production; PP: primary production. Abbreviations of lakes given in Table 1

\begin{tabular}{|c|c|c|c|c|c|c|}
\hline & $\begin{array}{c}\text { Epilimnion } \\
\text { (all lakes) }\end{array}$ & BL & FNE & FSW & ST & TW \\
\hline \multicolumn{7}{|l|}{ Free-living } \\
\hline Secchi depth & - & - & $-0.818^{\mathrm{a}}$ & $-0.846^{\mathrm{a}}$ & - & - \\
\hline Temperature & - & $-0.877^{a}$ & - & $0.772^{\mathrm{a}}$ & $0.704^{\mathrm{a}}$ & - \\
\hline $\mathrm{O}_{2}\left[\mathrm{mg} \mathrm{l}^{-1}\right]$ & - & - & - & - & $-0.787^{a}$ & - \\
\hline $\mathrm{pH}$ & $0.785^{\mathrm{b}}$ & - & - & - & - & $-0.747^{\mathrm{b}}$ \\
\hline Conductivity & - & $0.895^{\mathrm{a}}$ & - & - & $0.790^{c}$ & $0.713^{\mathrm{b}}$ \\
\hline Total nitrogen & - & $-0.705^{\mathrm{a}}$ & - & - & - & - \\
\hline Total phosphorous & - & $-0.738^{b}$ & - & - & - & $-0.722^{b}$ \\
\hline $\mathrm{DOC}$ & - & - & - & $0.797^{\mathrm{a}}$ & - & - \\
\hline BPP (total) & - & $-0.800^{\mathrm{a}}$ & - & - & - & - \\
\hline PP (total) & - & - & - & - & - & $0.701^{\mathrm{c}}$ \\
\hline $\mathrm{PP}(\leq 3.0, \geq 0.2 \mu \mathrm{m})$ & - & - & - & - & $-0.720^{\mathrm{c}}$ & - \\
\hline Phytoplankton & - & $-0.773^{b}$ & - & - & - & - \\
\hline \multicolumn{7}{|l|}{ Particle-associated } \\
\hline Secchi depth & - & - & - & - & $-0.757^{\mathrm{c}}$ & - \\
\hline Temperature & - & - & - & - & $-0.725^{\mathrm{a}}$ & - \\
\hline Conductivity & - & - & - & - & $0.821^{\mathrm{a}}$ & - \\
\hline Total phosphorous & - & $-0.846^{\mathrm{c}}$ & - & - & - & - \\
\hline $\mathrm{PP}(\leq 3.0, \geq 0.2 \mu \mathrm{m})$ & - & - & - & - & $-0.745^{\mathrm{a}}$ & - \\
\hline Zooplankton & - & - & - & - & $-0.750^{a}$ & - \\
\hline Phytoplankton & - & $-0.831^{\mathrm{c}}$ & - & - & - & - \\
\hline
\end{tabular}

may lead to distinct limitations, because large free-living cells (e.g. filamentous bacteria) cannot pass through these filters. As a result, these bacteria are then defined as particle-associated bacteria even though they are in fact free living. Filamentous bacteria are common in freshwater habitats and are selectively predated by bacterivorous protists (Pernthaler et al. 2004, Schauer et al. 2005). However, nonquantitative analyses of the bacterial communities in our study lakes by DAPI and CARD-FISH (catalyzed reporter deposition fluorescence in situ hybridization) indicated that filamentous bacteria were in low abundance (data not shown). Nevertheless, we cannot unambiguously state that our separation was always fully successful and yielded the 'real' free-living and particle-associated bacterial fractions. High numbers of cyanobacterial sequences in our clone libraries of particle-associated bacteria indicated that larger cells or colony-forming bacteria remained in the particle-associated fractions, and hence were not included with free-living bacterial communities.

The formation of lake-specific clusters within NMDS analyses of DGGE

\section{DISCUSSION}

\section{Differences in community structure of free-living and particle-associated bacteria}

To our knowledge, this is one of the first comprehensive studies of seasonal changes in bacterial community structure and dynamics in freshwater systems that consistently separated free-living from particle-associated bacteria. Our DGGE analyses revealed significant differences between both bacterial fractions in all lakes. This was in accordance with previous studies that used $\mathrm{a} \geq 3.0 \mu \mathrm{m}$ filtration step to differentiate between free-living and particle-associated bacteria (e.g. Crump et al. 1999, Riemann \& Winding 2001, Selje \& Simon 2003). Filter pore sizes for separating free-living from particle-associated bacteria are crucial and may greatly bias the analyses of bacterial communities of different size fractions. For example, Hollibaugh et al. (2000) did not observe any differences between particle-associated and free-living bacteria when using $1.0 \mu \mathrm{m}$ filters for separation, presumably because these filters may have also retained a large portion of free-living bacteria. Also, larger pore sizes banding patterns from all lakes was more pronounced for free-living than for particle-associated bacteria (Fig. 2A). Similar effects of environmental conditions on particles among lakes may have led to smaller differences among particle-associated bacterial communities, which may be indicative of adaptation by distinct bacterial communities to these microenvironments (Weiss et al. 1996, Grossart \& Simon 1998, Brachvogel et al. 2001). Lake snow aggregates are nutrient rich 'hot-spots' for limnetic bacteria, which leads to higher bacterial abundances, biomasses, and activities in aggregates than in the ambient water (Grossart \& Simon 1993, Middelboe et al. 1995, Simon et al. 2002). Although the studied lakes differed in their limnological features, the microenvironment of particles seems to be more similar among the lakes than does that of ambient water.

\section{Dynamics of bacterioplankton communities}

NMDS analyses of DGGE banding patterns indicated pronounced seasonal dynamics within freeliving and particle-associated bacterial communities of 
the 4 studied lakes (Fig. 2B). Seasonal changes in bacterioplankton community structures are common and may be linked to numerous environmental factors, such as phytoplankton succession, protozoan grazing, and viral lysis (Shiah \& Ducklow 1994, Hahn \& Höfle 1999, Yager et al. 2001, Brussaard et al. 2005). To identify factors controlling changes in bacterial community structure, we compared the DGGE profiles of the respective bacterial communities with 15 limnological variables. Our results indicated strong correlations (Pearson's $r \geq 0.800$ ) between free-living bacteria (Lake Breiter Luzin, NE and SW compartment of Lake Grosse Fuchskuhle) and certain environmental variables such as secchi depth, temperature, and total bacterial production (Table 4). Particle-associated bacteria showed strong correlations with conductivity, total phosphorus, and phytoplankton biomass in Lake Breiter Luzin and Lake Stechlin (Table 4). Statistically significant relationships with these variables have been previously demonstrated for total bacterial communities of different freshwater habitats (see e.g. Stepanauskas et al. 2003, Lindström et al. 2005, Schauer et al. 2005, Yannarell \& Triplett 2005). However, it remains unknown how limnological variables control bacterial communities. Inconsistent correlation patterns between the studied lakes suggest adaptation by distinct bacterial communities to lake-specific combinations of variables. Although bacterial communities differed between the studied lakes, trophic state seems to be irrelevant to the determination of bacterial community structure. As shown by our NMDS ordination analyses, differences between free-living and particle-associated bacterial communities indicated no relationship with the trophic gradient of the studied lakes. Dissimilarities among bacterial communities must therefore be caused by other factors.

In addition, changes in bacterial community composition are not only linked to autochthonous processes (e.g. phytoplankton blooms) but also to allochthonous factors. For example, riverine inlets or the input of allochthonous organic matter lead to substantial shifts in bacterial community structure (Crump et al. 2003, Lindström \& Bergström 2004). Since all studied lakes are independent from external water inflow, the input of riverine bacteria can be excluded unambiguously. All studied lakes are generally maintained by autochthonous processes, but leaf litter during fall and early winter leads to a significant input of allochthonous carbon into the lakes. For Lake Stechlin it was observed that carbon input by leaves can contribute almost a quarter of the total annual organic carbon input, which significantly increases ${ }^{14} \mathrm{C}$-glucose uptake by heterotrophic bacteria (H.-D. Babenzien pers. com.). The impact of leaf litter input on the dynamics of the bacterial commu- nities of the studied lakes is currently unknown and must be investigated in the future. However, formation of seasonal clusters within our NMDS analyses may provide a first indication that the above mentioned processes indeed affect bacterial community structure.

\section{Phylogenetic diversity of freshwater bacterial communities}

Clone libraries of $16 \mathrm{~S}$ rRNA gene fragments indicated distinct phylogenetic differences between freeliving and particle-associated bacteria of all lakes. As demonstrated by our phylogenetic analyses, all retrieved 16S rRNA gene sequences belonged to already known bacterial lineages (Hiorns et al. 1997, Glöckner et al. 2000, Zwart et al. 2002). The number of sequenced clones was too low to draw any general conclusion on the quantitative proportions of distinct bacterial lineages. Furthermore, our clone libraries were restricted to 2 selected time points - May (Lake Stechlin) and November 2003 (all lakes) — and hence may be rather limited in their phylogenetic information.

Free-living bacterial communities of the 4 studied lakes were dominated by Actinobacteria, Bacteroidetes, and Betaproteobacteria, whereas particle-associated bacterial communities mainly comprised sequences of Cyanobacteria and members of Bacteroidetes.

Bacteria of Class Actinobacteria were found predominantly in the free-living bacterial fractions of the studied lakes. Only 1 single sequence belonged to the particle-associated bacteria (Table 3). However, Actinobacteria do occur regularly on particles, as shown by a study on particle-associated bacterial communities that investigated Actinobacteria in detail using a specific DGGE approach (M. Allgaier et al. unpubl. data). Hence, proportions of particle-associated Actinobacteria were probably underestimated by our clone libraries. Due to a lack of Actinobacteria isolates, almost nothing is known about their physiology and ecological role in freshwater habitats.

Bacteria of the Bacteroidetes are common in freshwater habitats but also occur in other aquatic environments (Glöckner et al. 1999, Kirchman 2002, Eiler \& Bertilsson 2004). They are known to play an important role in the turnover of organic matter (Cottrell \& Kirchman 2000b) and are capable of degrading polymeric substrates such as cellulose and chitin (Kirchman 2002, Jam et al. 2005). Members of Bacteroidetes are well known as particle-associated bacteria, but are also common as free-living organisms (Crump et al. 1999, Eiler \& Bertilsson 2004, Schauer et al. 2005).

Low numbers of Betaproteobacteria in our clone libraries of particle-associated bacteria were in contra- 
diction to previous studies, where Betaproteobacteria were identified to be one of the dominating bacterial groups of particle-associated bacteria (Weiss et al. 1996, Grossart \& Simon 1998, Schweitzer et al. 2001). Members of Betaproteobacteria are widely distributed in freshwater habitats, and frequently dominate total bacterial communities. In Lake Grosse Fuchskuhle, Betaproteobacteria contributed up to $29 \%$ (NE compartment) and $42 \%$ (SW compartment) to total bacterial communities (Burkert et al. 2003). Nevertheless, the low numbers of Betaproteobacteria sequences in our clone libraries remain unexplained.

Clone libraries of particle-associated bacteria also revealed several sequences of Verrucomicrobia and Planctomycetes. Even though all sequences of Verrucomicrobia were found on particles, it is uncertain whether these bacteria are exclusively adapted to such microenvironments, as was demonstrated for Planctomycetes (Neef et al. 1998).

In summary, our results revealed clear seasonal dynamics within free-living and particle associated bacterial communities from all studied lakes. Significant differences were found between both fractions with respect to community structure and phylogenetic diversity. Bacterial communities were strongly correlated with limnological variables such as secchi depth, temperature, conductivity, phosphorus, bacterial production, and phytoplankton biomass. However, no uniform correlation pattern among bacterial communities and measured limnological variables was observed when data from all lakes were compared. This may indicate adaptation by individual bacterial communities to specific environmental conditions in a given lake. Phylogenetically, almost all cloned and sequenced 16S rRNA gene fragments belonged to already known freshwater clusters. Members of the Bacteroidetes occurred in both bacterial fractions, whereas Actinobacteria, Alpha- and Betaproteobacteria mainly occurred within the free-living bacteria. To obtain further information on relationships between bacterioplankton communities and environmental variables, more specific studies on distinct phylogenetic lineages and/or defined seasonal periods are required.

Acknowledgements. We thank E. Mach for technical assistance during sampling and in the laboratory. R. Koschel, L. Krienitz, and P. Kasprzak are thanked for providing data on chemistry, phytoplankton and zooplankton biomasses, and community composition, respectively. We also thank K. Pohlmann for her helpful comments on statistical analyses and the text. We appreciate the helpful comments of 3 anonymous reviewers on an earlier version of this manuscript. This study was supported by the Leibniz foundation and by a grant from the Studienstiftung des deutschen Volkes given to M. Allgaier.

\section{LITERATURE CITED}

Allgaier M, Grossart HP (2006) Diversity and seasonal dynamics of Actinobacteria in four lakes of Northeastern Germany. Appl Environ Microbiol 72:3489-3497

Bittl T, Babenzien HD (1996) Microbial activities in an artificially divided acidic lake. Arch Hydrobiol Adv Limnol 48: 113-121

Brachvogel T, Schweitzer B, Simon M (2001) Dynamics and bacterial colonization of microaggregates in a large mesotrophic lake. Aquat Microb Ecol 26:23-35

Brinkhoff T, Muyzer G (1997) Increased species diversity and extended habitat range of sulfur-oxidizing Thiomicrospira spp. Appl Environ Microbiol 63:3789-3796

Brussaard CPD, Mari X, Van Bleijswijk JDL, Veldhuis MJW (2005) A mesocosm study of Phaeocystis globosa (Prymnesiophyceae) population dynamics II. Significance for the microbial community. Harmful Algae 4:875-893

Burkert U, Warnecke F, Babenzien HD, Zwirnmann E, Pernthaler J (2003) Members of a readily enriched $\beta$-proteobacterial clade are common in surface waters of a humic lake. Appl Environ Microbiol 68:6550-6559

Clarke KR, Green RH (1988) Statistical design and analysis for a 'biological effects' study. Mar Ecol Prog Ser 46:213-226

Cotner JB, Biddanda BA (2002) Small players, large role: microbial influence on biogeochemical processes in pelagic aquatic ecosystems. Ecosystems 5:105-121

Cottrell MT, Kirchman DL (2000a) Community composition of marine bacterioplankton determined by 16S rRNA gene clone libraries and fluorescence in situ hybridization. Appl Environ Microbiol 66:5116-5122

Cottrell MT, Kirchman DL (2000b) Natural assemblages of marine Proteobacteria and members of the Cytophaga/ Flavobacteria cluster consuming low- and high-molecular weight dissolved organic matter. Appl Environ Microbiol 66:1692-1697

Crump BC, Armbrust EV, Baross JA (1999) Phylogenetic analysis of particle-attached and free-living bacterial communities in the Columbia river, its estuary, and the adjacent coastal ocean. Appl Environ Microbiol 65:3192-3204

Crump BC, Kling GW, Bahr M, Hobbie JE (2003) Bacterioplankton community shifts in an arctic lake correlate with seasonal changes in organic matter source. Appl Environ Microbiol 69:2253-2268

Eiler A, Bertilsson S (2004) Composition of freshwater bacterial communities associated with cyanobacterial blooms in four Swedish lakes. Environ Microbiol 6:1228-1243

Glöckner FO, Fuchs B, Amann R (1999) Bacterioplankton composition of lakes and oceans: a first comparison based on fluorescence in situ hybridization. Appl Environ Microbiol 65:3721-3726

Glöckner FO, Zaichikov E, Belkova N, Denissova L, Pernthaler J, Pernthaler A, Amann R (2000) Comparative 16S rRNA analysis of lake bacterioplankton reveals globally distributed phylogenetic clusters including an abundant group of Actinobacteria. Appl Environ Microbiol 66:5053-5065

Grossart HP, Simon M (1993) Limnetic macroscopic organic aggregates (lake snow): abundance, characteristics, and bacterial dynamics in Lake Constance. Limnol Oceanogr 38:532-546

Grossart HP, Simon M (1998) Bacterial colonization and microbial decomposition of limnetic organic aggregates (lake snow). Aquat Microb Ecol 15:127-140

Hahn MW, Höfle MG (1999) Flagellate predation on a bacterial model community: interplay of size-selective grazing, specific bacterial cell size, and bacterial community composition. Appl Environ Microbiol 65:4863-4872 
Hehmann A, Krienitz L, Koschel R (2001) Long-term phytoplankton changes in an artificially divided, top-down manipulated humic lake. Hydrobiologia 448:83-96

Hiorns WD, Methé BA, Nierzwickibauer SA, Zehr JP (1997) Bacterial diversity in Adirondack mountain lakes as revealed by $16 \mathrm{~S}$ rRNA gene sequences. Appl Environ Microbiol 63:2957-2960

Hollibaugh JT, Wong PS, Murell MC (2000) Similarity of particle-associated and free-living bacterial communities in northern san Francisco Bay, California. Aquat Microb Ecol 21:103-114

Jam M, Flament D, Allouch J, Potin P and 6 others (2005) The endo-beta-agarases AgaA and AgaB from the marine bacterium Zobellia galactinovorans: two paralogue enzymes with different molecular organizations and catalytic behaviour. Biochem J 385:703-713

Kasprzak P (1993) The use of an artificially divided bog lake in food web studies. Verh Int Verein Limnol 25:652-656

Kent AD, Jones SE, Yannarell AC, Graham JM, Lauster GH, Kratz TK, Triplett EW (2004) Annual patterns in bacterioplankton community variability in a humic lake. Microb Ecol 48:550-560

Kirchman DL (2002) The ecology of Cytophaga-Flavobacteria in aquatic environments. FEMS Microbiol Ecol 39:91-100

Koschel R (1995) Manipulation of whole lake ecosystems and long term limnological observations of the BrandenburgMecklenburg lake district. Int Rev Gesamten Hydrobiol 80:1-12

Koschel R, Casper P, Gonsiorczyk T, Rossberg R, Wauer G (2006) Hypolimnetic Al- and $\mathrm{CaCO}_{3}$-treatments and aeration for restoration of a stratified eutrophic hardwater lake (Lake Tiefwarensee, Mecklenburg-Vorpommern, Germany). Verh Internat Verein Limnol (in press)

Langenheder S, Jürgens K (2001) Regulation of bacterial biomass and community structure by metazoan and protozoan predation. Limnol Oceanogr 46:121-134

Lindström ES, Bergström AK (2004) Influence of inlet bacteria on bacterioplankton assemblage composition in lakes of different hydraulic retention time. Limnol Oceanogr 49: $125-136$

Lindström ES, Kamst-van Agterveld MP, Zwart G (2005) Distribution of typical freshwater bacterial groups is associated with $\mathrm{pH}$, temperature, and lake water retention time. Appl Environ Microbiol 71:8201-8206

McCune B, Grace JB (2002) Analysis of ecological communities. MjM Software Design, Glenden Beach, OR

Mehner T, Diekmann M, Brämik U, Lemcke R (2005) Composition of fish communities in German lakes as related to lake morphology, trophic state, shore structure, and human-use intensity. Freshwater Biol 50:70-85

Methé BA, Zehr JP (1999) Diversity of bacterial communities in Adirondack lakes: Do species assemblages reflect lake water chemistry? Hydrobiologia 401:77-96

Middelboe M, Søndergaard M, Letarte Y, Borch NH (1995) Attached and free-living bacteria: production and polymer hydrolysis during a diatom bloom. Appl Environ Microbiol 59:3916-3921

Morris CE, Bardin M, Berge O, Frey-Klett P and 6 others (2002) Microbial biodiversity: approaches to experimental design and hypothesis testing in primary scientific literature from 1975 to 1999. Appl Environ Microbiol 66: 592-616

Muylaert K, Van der Gucht K, Vloemans N, de Meester L, Gillis M, Vyverman W (2002) Relationship between bacterial community composition and bottom-up versus topdown variables in four eutrophic shallow lakes. Appl Environ Microbiol 68:4740-4750
Muyzer G, Dewaal EC, Uitterlinden AG (1993) Profiling of complex microbial populations by denaturing gradient gel electrophoresis analysis of polymerase chain reactionamplifies genes coding for 16S ribosomal-RNA. Appl Environ Microbiol 59:695-700

Muyzer G, Teske A, Wirsen CO, Jannasch HW (1995) Phylogenetic relationship of Thiomicrospira species and their identification in deep-sea hydrothermal vent samples by denaturing gradient gel electrophoresis of $16 \mathrm{~S}$ rDNA fragments. Arch Microbiol 164:165-172

Muyzer G, Brinkhoff T, Nübel U, Santegoeds C, Schäfer H, Wawer C (1998) Denaturing gradient gel electrophoresis (DGGE) in microbial ecology. In: Akkerman ADL, van Elsas JD, Bruijn FJ (eds) Molecular microbial ecology manual. Kluwer Academic, Dordrecht

Neef A, Amann R, Schlesner H, Schleifer KH (1998) Monitoring a widespread bacterial group: in situ detection of Planctomycetes with 16S rRNA-target probes. Microbiology 144:3257-3266

Pernthaler J, Posch T, Šimek K, Vrba J and 5 others (2001) Predator-specific enrichment of Actinobacteria from a cosmopolitan freshwater clade in mixed continuous culture. Appl Environ Microbiol 67:2145-2155

Pernthaler J, Zöllner E, Warnecke F, Jürgens K (2004) Bloom of filamentous bacteria in a mesotrophic lake: identity and potential controlling mechanism. Appl Environ Microbiol 70:6272-6281

Pinhassi J, Hagström $\AA$ (2000) Seasonal succession in marine bacterioplankton. Aquat Microb Ecol 21:245-256

Premazzi G, Chiaudani G (1992) Ecological quality of surface waters: quality assessments schemes for European Community lakes. JRC Report EUR 14563 EN, Brussels

Rappé MS, Vergin K, Giovannoni SJ (2000) Phylogenetic comparison of a coastal bacterioplankton community with its counterparts in open ocean and freshwater systems. FEMS Microbiol Ecol 33:219-232

Riemann L, Winding A (2001) Community dynamics of freeliving and particle-associated bacterial assemblages during a freshwater phytoplankton bloom. Microb Ecol 42: $274-285$

Schauer M, Kamenik C, Hahn MW (2005) Ecological differentiation within a cosmopolitan group of planktonic freshwater bacteria (SOL cluster, Saprospiraceae, Bacteroidetes). Appl Environ Microbiol 71:5900-5907

Schweitzer B, Huber I, Amann R, Ludwig W, Simon M (2001) $\alpha$ - and $\beta$-Proteobacteria control the consumption and release of amino acids on lake snow aggregates. Appl Environ Microbiol 67:632-645

Selje N, Simon M (2003) Composition and dynamics of particle-associated and free-living bacterial communities in the Weser Estuary, Germany. Aquat Microb Ecol 30: 221-237

Shiah FK, Ducklow HW (1994) Temperature regulation of heterotrophic bacterioplankton abundance, production, and specific growth rate in Chesapeake Bay. Limnol Oceanogr 39:1243-1258

Simon M, Grossart HP, Schweitzer B, Ploug H (2002) Microbial ecology of organic aggregates in aquatic ecosystems. Aquat Microb Ecol 28:175-211

Stepanauskas R, Moran MA, Bergamaschi BA, Hollibaugh JT (2003) Covariance of bacterioplankton composition and environmental variables in a temperate delta system. Aquat Microb Ecol 31:85-98

Trusova MY, Gladyshev MI (2002) Phylogenetic diversity of winter bacterioplankton of eutrophic Siberian reservoirs as revealed by $16 \mathrm{~S}$ rRNA gene sequences. Microb Ecol 44: 252-259 
Van der Gucht K, Vandekerckhove T, Vloemans N, Cousin S and 6 others (2005) Characterization of bacterial communities in four freshwater lakes differing in nutrient load and food web structure. FEMS Microb Ecol 53:205-220

Weiss P, Schweitzer B, Amann R, Simon M (1996) Identification in situ and dynamics of bacteria on limnetic organic aggregates (lake snow). Appl Environ Microbiol 62: 1998-2005

Yager PL, Connelly TL, Mortazavi B, Wommak KE, Band N, Bauer JE, Opsahl S, Hollibaugh JT (2001) Dynamic bacterial and viral response to an algal bloom at subzero

Editorial responsibility: Staffan Kjelleberg,

Sydney, New South Wales, Australia temperatures. Limnol Oceanogr 46:790-801

Yannarell AC, Triplett EW (2005) Geographic environmental sources of variation in lake bacterial community composition. Appl Environ Microbiol 71:227-239

Zwart G, Crump BC, Kamst-van Agterveld MP, Hagen F, Han SK (2002) Typical freshwater bacteria: an analysis of available 16S rRNA gene sequences from plankton of lakes and rivers. Aquat Microb Ecol 28:141-155

Zwisler W, Selje N, Simon M (2003) Seasonal patterns of the bacterioplankton community composition in a large mesotrophic lake. Aquat Microb Ecol 31:211-225

Submitted: May 11, 2006; Accepted: September 4, 2006 Proofs received from author(s): November 6, 2006 